\title{
PERBEDAAN HASIL PEMERIKSAAN LDL DIREK (METODE HOMOGEN) DENGAN INDIREK (FORMULA FRIEDEWALD) PADA PASIEN PENDERITA DISLIPIDEMIA DI RUMAH SAKIT ISLAM JAKARTA CEMPAKA PUTIH
}

\author{
*Cahyawati Rahayu'), Afisya Agriyanti'1) \\ ${ }^{1}$ Program Studi D III Analis Kesehatan, Fakultas Kesehatan, Universitas Mohammad Husni Thamrin \\ Correspondence author: Cahyawati Rahayu, rahayucahyawati@gmail.com, Jakarta, Indonesia
}

\begin{abstract}
ABSTRAK
Pemeriksaan LDL metode direk (homogen) mempunyai kemampuan otomatisasi penuh dalam penentuan LDL kolesterol secara langsung. Selain itu juga memerlukan volume sampel yang kecil dan waktu pemeriksaan yang singkat, sedangkan pemeriksaan LDL kolesterol indirek (formula Friedewald) banyak digunakan, dimana kolesterol trigliserida dan HDL kolesterol diukur, kemudian LDL kolesterol dihitung dengan menggunakan rumus Friedewald. Tujuan penelitian ini adalah untuk melihat perbedaan hasil LDL direk (metode homogen) dengan indirek (formula Friedewald) pada pasien penderita dislipidemia. Data diperoleh dari hasil pemeriksaan kadar profil lipid (kolesterol total, trigliserida, HDL kolesterol dan LDL kolesterol) pada pasien penderita dislipidemia di RS Islam Jakarta Cempaka Putih kemudian data diolah dengan menggunakan uji Mann Whitney pada analisis statistika SPSS.112 sampel yang diteliti didapatkan rata-rata hasil pemeriksaan LDL direk (homogen) adalah $138.473 \mathrm{mg} / \mathrm{dl}$ dan hasil pemeriksaan LDL indirek (formula Friedewald) adalah 135.802 $\mathrm{mg} / \mathrm{dl}$. Berdasarkan perhitungan statistik uji Mann Whitney didapatkan hasil 0.625, disimpulkan bahwa tidak ada perbedaan yang signifikan karena $\mathrm{p}>0.005$ maka Ho diterima. Kedua metode sama baiknya dan dapat digunakan, untuk metode indirek (formula Friedewald) dapat digunakan ketika kadar trigliserida kurang dari 400 mg/dl.
\end{abstract}

Kata Kunci : Dislipidemia, Pemeriksaan LDL direk (metode homogen), Pemeriksaan LDL indirek (Formula Friedewald)

\begin{abstract}
LDL examination of the direk (homogeneous) method has the ability to fully automate in the determination of LDL cholesterol directly. It also requires a small sample volume and a short examination time, while ldl examination of indirek cholesterol (Friedewald formula) is widely used, where triglyceride cholesterol and HDL cholesterol are measured, then LDL cholesterol is calculated using friedewald formula. The purpose of this study was to look at differences in LDL direk (homogeneous methods) results with indirek (Friedewald formula) in patients with dislipidemia. Data obtained from the results of examination of lipid profile levels (total cholesterol, triglycerides, HDL cholesterol and LDL cholesterol) in patients with dislipidemia at Jakarta Cempaka Putih Islamic Hospital then the data was processed using mann whitney test on statistical analysis of SPSS.112 the sample studied obtained the average ldl direk (homogeneous) test results were $138,473 \mathrm{mg} / \mathrm{dl}$ and the results of ldl indirek examination (Friedewald formula) was $135.802 \mathrm{mg} / \mathrm{dl}$. Based on mann whitney's statistical calculations obtained results of 0.625 , it was concluded that there was no significant difference because $\mathrm{p}>0.005$ then Ho was accepted. Both methods are just as good and can be used, for the indirek method (Friedewald formula) can be used when triglyceride levels are less than $400 \mathrm{mg} / \mathrm{dl}$.
\end{abstract}

Keywords $\quad$ : Dislipidemia, LDL direk examination (homogeneous method), LDL indirek examination (Friedewald Formula)

Open Journal System (OJS): journal.thamrin.ac.id

http://journal.thamrin.ac.id/index.php/anakes/issue/view/33 


\section{PENDAHULUAN}

Dislipidemia adalah suatu kelainan metabolisme lipid yang ditandai dengan peningkatan kadar kolesterol total (hiperkolesterolemia), peningkatan kadar trigliserida (TG), peningkatan kadar low-density lipoprotein cholesterol (LDL-C), dan penurunan kadar high-density lipoprotein cholesterol (HDL-C) dalam darah (Grundy, 2002).

Prevalensi dislipidemia di dunia mengalami peningkatan yang sangat signifikan dalam beberapa tahun terakhir, terutama di negara maju. Studi National Health and Nutrition Examination Survey (NHANES) tahun 2003-2006 menyatakan sekitar 53\% orang dewasa di Amerika Serikat mempunyai kelainan metabolisme lipid. Sekitar 21\% dari orang dewasa di Amerika Serikat dinyatakan menderita Mixed Dyslipidemia (LDL-C yang tinggi dengan HDL-C yang rendah atau trigliserida yang tinggi) dan hampir 6\% mempunyai kelainan pada ketiga komponen lipid tersebut (Toth, Potter, \& Ming, 2012).

Insidensi dislipidemia berdasarkan umur telah diteliti mengalami pergeseran ke arah usia lebih muda. Menurut studi NHANES tahun 1999-2006, 20.3\% remaja usia 12-19 tahun menderita dislipidemia dengan Body Mass Index (BMI) yang bervariasi, 14.2\% BMI normal, $22.3 \%$ Overweight, dan $42.9 \%$ obesitas. Hasil penelitian tersebut memberikan pandangan diperlukannya Screening profil lipid pada remaja dan dewasa muda terutama pada individuindividu dengan BMI di atas nilai normal (Center of Disease Control and Prevention (CDC), 2010).

Pada penelitian yang dilakukan oleh Sudijanto Kamso pada tahun 2004 terhadap 656 responden di 4 kota besar di Indonesia (Jakarta, Bandung, Yogyakarta, dan Padang) didapatkan keadaan dislipidemia berat (Kolesterol total $>204 \mathrm{mg} / \mathrm{dl}$ ) pada orang berusia di atas 55 tahun didapatkan paling banyak di Padang dan Jakarta ( $>56 \%)$, diikuti oleh mereka yang tinggal di Bandung (52.2\%) dan Yogyakarta (27.7\%). Pada penelitian ini juga didapatkan dislipidemia lebih banyak dtemukan pada wanita $(56.2 \%)$ dibandingkan pada pria (47\%) (Gandha, 2009).

Angka kejadian penyakit kardiovaskuler sangat berkaitan dengan kejadian dislipidemia. Kadar LDL-C merupakan suatu faktor risiko independen terjadinya penyakit kardiovaskuler. Deteksi dini kadar LDL-C pada kelompok pasien dengan faktor risiko penyakit kardiovaskuler memungkinkan terapi dan tindakan pencegahan dapat dilaksanakan lebih dini.

Open Journal System (OJS): journal.thamrin.ac.id 


\section{National Cholesterol Education Program-Adult Treatment Panel (NCEP-ATP)}

merekomendasikan pengukuran LDL-C sebagai kriteria primer diagnosis hiperkolesterolemia (Grundy, 2002).

Pengukuran kadar LDL ditentukan dengan menggunakan metode direk dan Formula Friedewald. Pemeriksaan LDL metode direk lebih sederhana, cepat dan memberikan hasil yang lebih akurat yaitu mencapai $95 \%$, disamping itu penderita tidak perlu puasa oleh karena kadar LDL tidak dipengaruhi langsung oleh makanan yang baru dimakan sedangkan rumus Friedewald menghitung kadar LDL dengan melibatkan tiga parameter lipid lainnya (kolesterol, trigliserida dan HDL) sehingga hasil perhitungannya tergantung pada ketepatan dari ketiga parameter tersebut. Pasien perlu berpuasa sekurang kurangnya 10 jam dan sebaiknya 12 jam dan rumus Friedewald tidak dapat digunakan bila kadar trigliserida lebih dari $400 \mathrm{mg} / \mathrm{dl}$ (Kosasih dan Kosasih, 2008).

LDL kolesterol dapat dihitung tanpa biaya tambahan dari hasil pemeriksaan kolesterol total, HDL kolesterol dan trigliserida. Bila menggunakan metode homogen, maka harga pemeriksaan profil lipid akan menjadi dua kali lipat karena biaya reagen Homogenous assay untuk LDL kolesterol kurang lebih harganya sama dengan total ketiga parameter di atas. Kelemahan cara indirek (Friedewald) yaitu, bila kilomikron meninggi, kesalahan menghitung menjadi besar. Pemeriksaan laboratorium, rumus Friedewald tidak dapat digunakan bila kadar trigliserida $>400 \mathrm{mg} / \mathrm{dl}$ (Murat, dkk, 2008).

Berdasarkan penelitian yang dilakukan oleh Widianto dkk (2015) mengenai Perbandingan nilai LDL Indirek dan Direk pada kadar Trigliserida $<200 \mathrm{mg} / \mathrm{dl}$ dan antara 200-400 mg/dl dengan kesimpulan kadar trigliserida $<200 \mathrm{mg}$ /dl tidak ada perbedaan yang signifikan antara hasil pemeriksaan LDL metode direk dengan indirek tetapi pada kadar trigliserida antara 200$400 \mathrm{mg} / \mathrm{dl}$ terdapat perbedaan yang signifikan antara hasil pemeriksaan LDL metode direk dengan indirek.

Berdasarkan uraian diatas, maka perumusan masalahnya adalah apakah terdapat perbedaan hasil yang signifikan pada pemeriksaan LDL direk (metode homogen) dengan indirek (Formula Friedewald) pada pasien penderita dislipidemia di Rumah Sakit Islam Jakarta Cempaka Putih

Open Journal System (OJS): journal.thamrin.ac.id 


\section{METODOLOGI PENELITIAN}

Penelitian ini dilakukan melalui pengambilan data periode Juli 2017 sampai Juni 2018 di Laboratorium Rumah Sakit Islam Jakarta Cempaka Putih. Waktu penelitian dilaksanakan pada tanggal 31 Juli sampai 3 Agustus 2018. Populasi pada penelitian ini adalah pasien penderita dislipidemia di Rumah Sakit Islam Jakarta Cempaka Putih. Sampel pada penelitian ini adalah data hasil pemeriksaan profil lipid dengan metode direk (homogen) dan indirek (formula Friedewald) pada pasien penderita dislipidemia periode Juli 2017 sampai Juni 2018. Penelitian ini dilakukan dengan mengumpulkan data-data sekunder dari Rumah Sakit Islam Jakarta Cempaka Putih dengan tahapan : Mengajukan surat izin permohonan untuk mengambil data kepada bagian Direktur atau Laboratorium Rumah Sakit Islam Jakarta Cempaka Putih. Mencari data pasien penderita dislipidemia di Rekam Medik dan memilih data pasien penderita dislipidemia pada program Laboratorium Information System (LIS) yang ada di Laboratorium Rumah Sakit Islam Jakarta Cempaka Putih. Mencatat data hasil pemeriksaan dan data penunjang lainnya seperti nama, umur, jenis kelamin. Melakukan pengolahan data yang disajikan berupa tabel. Data diperoleh dari hasil pemeriksaan kadar profil lipid (kolesterol total, trigliserida, HDL kolesterol dan LDL kolesterol) pada pasien penderita dislipidemia kemudian data diolah dengan menggunakan uji Mann Whitney pada analisis statistika SPSS (untuk mengetahui perbedaan).

\section{HASIL DAN PEMBAHASAN}

\section{Hasil}

Penelitian ini bertujuan untuk melihat ada tidaknya perbedaan hasil pada pemeriksaan LDL kolesterol direk (metode homogen) dengan indirek (Formula Friedewald) terhadap 112 sampel pada pasien penderita Dislipidemia. Hasil yang diperoleh penulis uraikan sebagai berikut :

Open Journal System (OJS): journal.thamrin.ac.id 
Tabel 1.

Distribusi Frekuensi Pemeriksaan

LDL Direk (Metode Homogen) dengan Indirek (Formula Friedewald)

\begin{tabular}{lcc}
\hline & Metode Direk & Metode Indirek \\
\hline Nilai Tertinggi & 285.0 & \\
Nilai Terendah & 57.0 & 286.0 \\
Rata-rata & 138.473 & 54.2 \\
Standar Deviasi & 43.4478 & 135.802 \\
\hline
\end{tabular}

Pada tabel 5 dapat dilihat nilai rata-rata hasil pemeriksaan LDL direk (Metode Homogen) adalah $138.473 \mathrm{mg} / \mathrm{dl}$ dengan standar deviasi (SD) $43.4478 \mathrm{mg} / \mathrm{dl}$ dan rata-rata hasil pemeriksaan LDL Indirek (Formula Friedewald) adalah 135.802 mg/dl dengan standar deviasi (SD) $45.3795 \mathrm{mg} / \mathrm{dl}$.

Uji Mann Whitney untuk mengetahui ada atau tidaknya perbedaan rata-rata data dua sampel yang tidak berpasangan. Dalam uji beda ini sampel yang digunakan tidak harus sama jumlahnya. Sementara itu, perbedaan yang mendasar antar uji tersebut adalah bahwa uji independen sampel $\mathrm{t}$ test merupakan bagian dari metode statistik parametrik, sedangkan uji Mann Whitney adalah bagian dari statistik non parametrik.

Tabel 2.

Hasil Uji Mann Whitney

\begin{tabular}{|l|r|}
\hline & \multicolumn{1}{|c|}{ LDL } \\
\hline Mann-Whitney U & 6035.000 \\
\hline Wilcoxon W & 12363.000 \\
$Z$ & -.489 \\
\hline $\begin{array}{l}\text { Asymp. Sig. (2- } \\
\text { tailed) }\end{array}$ & .625 \\
\hline
\end{tabular}

Pada uji Mann Whitney didapatkan hasil 0.625, disimpulkan bahwa tidak ada perbedaan yang signifikan karena $\mathrm{p}>0.05$ maka Ho diterima.

\section{Pembahasan}

Open Journal System (OJS): journal.thamrin.ac.id 
Pada tabel 1 nilai rata-rata hasil pemeriksaan LDL Direk (metode homogen) adalah $138.473 \mathrm{mg} / \mathrm{dl}$ dengan standar deviasi (SD) $43.4478 \mathrm{mg} / \mathrm{dl}$ dan rata-rata hasil pemeriksaan LDL Indirek (Formula Friedewald) adalah $135.802 \mathrm{mg} / \mathrm{dl}$ dengan standar deviasi (SD) $45.3795 \mathrm{mg} / \mathrm{dl}$.

Pada penelitian ini dilakukan uji Mann Whitney karena data berdistribusi tidak normal. Berdasarkan tabel uji Mann Whitney diketahui bahwa nilai p-value adalah 0.625 artinya tidak ada perbedaan yang bermakna pada pemeriksaan LDL direk (metode homogen) dengan indirek (Formula Friedewald) karena data LDL direk dan indirek yang didapat mempunyai selisih yang sedikit bahkan ada beberapa data yang mempunyai hasil yang sama.

Hasil penelitian ini sama seperti hasil penelitian yang dilakukan oleh Desty Ivat Vinia (2014) yang disimpulkan rata-rata hasil pemeriksaan LDL direk $116.67 \mathrm{mg} / \mathrm{dl}$ dengan Standar Deviasi (SD) $37.236 \mathrm{mg} / \mathrm{dl}$, rata-rata hasil pemeriksaan LDL indirek $115.81 \mathrm{mg} / \mathrm{dl}$ dengan Standar Deviasi (SD) $39.236 \mathrm{mg} / \mathrm{dl}$ dan hasil uji statistik t independen 0.909 artinya tidak ada perbedaan bermakna pada pemeriksaan LDL direk (metode homogen) dengan LDL indirek (formula Friedewald).

Sampel yang digunakan adalah 112 sampel pasien penderita Dislipidemia periode Juli 2017 sampai Juni 2018 di Rumah Sakit Islam Jakarta Cempaka Putih.

LDL kolesterol penting dalam penatalaksanaan dislipidemia karena angka kejadian penyakit kardiovaskuler sangat berkaitan dengan kejadian dislipidemia, dan untuk mencegah terjadinya aterosklerosis sehingga diperlukan pemeriksaan yang akurat.

Pemeriksaan LDL direk (metode homogen) mempunyai kemampuan otomatisasi penuh dalam penentuan LDL secara langsung, memerlukan volume sampel yang sedikit dan waktu pemeriksaan yang singkat tetapi harga reagen yang tergolong mahal sedangkan pemeriksaan LDL indirek (Formula Friedewald) sangat bergantung pada pemeriksaan profil lipid lainnya, kelemahan metode indirek bila kilomikron meninggi kesalahan menghitung menjadi besar dan formula Friedewald tidak dapat digunakan bila kadar trigliserida $>400$ $\mathrm{mg} / \mathrm{dl}$.

Pemeriksaan LDL direk (metode homogen) dan indirek (formula Friedewald) sama baiknya karena tidak ada perbedaan hasil yang signifikan, kedua metode tersebut bisa dipakai sesuai kebutuhan tetapi ada baiknya laboratorium klinik menggunakan metode direk karena hasil lebih akurat dan metode direk bisa dipakai walaupun kadar trigliserida $>400 \mathrm{mg} / \mathrm{dl}$. 


\section{SIMPULAN}

Dari hasil data terhadap 112 sampel pemeriksaan LDL direk (metode homogen) dan indirek (Formula Friedewald) pada pasien penderita dislipidemia periode Juli 2017 sampai Juni 2018 di Rumah Sakit Islam Jakarta Cempaka Putih dan pembahasan yang sudah diuraikan, maka penulis dapat menarik kesimpulan sebagai berikut:

Nilai rata-rata hasil pemeriksaan LDL Direk (metode homogen) adalah $138.473 \mathrm{mg} / \mathrm{dl}$ dengan standar deviasi (SD) $43.4478 \mathrm{mg} / \mathrm{dl}$ dan rata-rata hasil pemeriksaan LDL Indirek (Formula Friedewald) adalah $135.802 \mathrm{mg} / \mathrm{dl}$ dengan standar deviasi (SD) $45.3795 \mathrm{mg} / \mathrm{dl}$.

Pada pemeriksaan LDL Direk (metode homogen) dan LDL Indirek (Formula Friedewald) dengan uji Mann Whitney didapatkan hasil $0.625(>0.05)$ yang artinya tidak ada perbedaan yang bermakna pada kedua metode pemeriksaan LDL tersebut.

\section{UCAPAN TERIMA KASIH}

Penulis mengucapkan terima kasih kepada Rumah Sakit Islam Jakarta Cempaka Putih dan Prodi D III Analis Kesehatan Fakultas Kesehatan Universitas MH Thamrin. dalam penelitian ini.

\section{DAFTAR PUSTAKA}

1. Berg JM, Tymoczko JL, Stryer L. 2012. Biochemistry $7^{\text {th }}$ edition. New York: W. H. Freeman.

2. Can Murat., dkk. 2008. Is direct method of loe density lipoprotein cholesterol measurement appropriate of targeting lipid lowering therapy.

3. Gandha, N. (2009). Hubungan Perilaku Dengan Prevalensi Dislipidemia Pada Masyarakat Kota Ternate Tahun 2008. 5-13.

4. Grundy, S.M. (2002). Detection, Evaluation, and Treatment of High Blood Cholesterol in Adults (Adult Treatment Panel III) Final Report. National Institutes of Health.

5. Hardjoeno, H. dkk, 2013, Interpretasi Hasil Laboratorium Diagnostik, LEPHAS, Makasar

6. Irianto K, 2014. Epidemiologi Penyakit Menular dan Tidak Menular Panduan Klinis. 263-264

Open Journal System (OJS): journal.thamrin.ac.id

http://journal.thamrin.ac.id/index.php/anakes/issue/view/33 
7. Kee JL., 2008. Pedoman Pemeriksaan Laboratorium \& Diagnostik. Buku Kedokteran EGC, Cetakan I Edisi 6, Jakarta.

8. Kosasih E.N. dan Kosasih A.S., 2008, Tafsiran Hasil Pemeriksaan Laboratorium Klinik, Edisi Kedua, Karisma Publishing Group, Tangerang.

9. Lembaga Ilmu Pengetahuan Indonesia (LIPI). 2009. Kolesterol.Pangan dan Kesehatan. UPT-Balai Informasi Teknologi,.

10. Nauck M, Warnick GR, Rifai N. Methods for Measurements of LDL-Cholesterol: A Critical Assesment of Direct Measurements by Homogenous Assay versus Calculation. ClinChem $2002: 48(2): 236-54$

11. PERKI, 2013, Pedoman Tatalaksana Dislipidemia, edisi pert., Perhimpunan Dokter Spesialis Kardiovaskular Indonesia, Jakarta.

12. Pranoto H, Edijanto SP. 2003. Pemeriksaan Kolesterol LDL Metode Homogen (Homogenous Assay). Surabaya. Divisi Kimia Klinik Laboratorium/Instalasi Patologi Klinik Fakultas Kedokteran Unair/RSU dr. Soetomo.

13. Prevention, C. f. (2010, January 22) Retrieved January 13, 2013, from CDC.gov: http://www.cdc.gov/mmwrhtml $/ \mathrm{mm} 5902 \mathrm{a} 1 / \mathrm{htm}$

14. Soeharto, I., 2004. Serangan Jantung dan Stroke Hubungannya dengan Lemak dan Kolesterol. PT Gramedia Pustaka Utama, Jakarta. 42-43

15. Tanno Kozo, dkk. 2010. Comparison of low density lipoprotein cholesterol measured by a direct homogenous assay and by the fridewald formula in a large community population.: 1774-1780

16. Tanuwijaya S. Recent development in pathogenesis of atherosclerosis, in Atherosclerosis from theory to clinical practice, Semarang Cardiology-Update (Mini Cardilogy - Update III), BP Universitas Diponegoro, Semarang : 2003)

17. Toth, P.P., Ptter, D., \& Ming,E.E. (2012). Prevalence of lipid abnormalities in the United States: the National Health and Nutrition Examination Survey 2003-2006. J Clin Lipidol, 4, 325-30.

Open Journal System (OJS): journal.thamrin.ac.id 